\title{
POLITISI LOKAL DAN ZIARAH MENYINGKAP HAJAT MELALUI ALQURAN KUNO BISMO
}

\author{
Arif Chasanul Muna \\ Institut Agama Islam Negeri (IAIN) Pekalongan \\ arif_chasanul_muna@yahoo.com \\ Ahmad Fauzan \\ Institut Agama Islam Negeri (IAIN) Pekalongan \\ ahmedjogjaa@gmail.com
}

\begin{abstract}
Pilgrimage is an activity that has become a tradition among Muslims in Java. One of the most visited destinations is the village of Bismo. In the village there are relics of the saints, one of which is an ancient Qur'an manuscript that believed to be the handwriting of Sunan Bonang (1465-1525). This paper aims to examine the history and practice of pilgrimage rituals in Bismo, and the reception of local politicians to the rituals of pilgrimage and the ancient Qur'an manuscript in Bismo. Using an anthropological approach, this paper concludes that (1) the practice of pilgrimage rituals in Bismo is unique, in addition to reading prayers as they are carried out elsewhere, pilgrims who have special intentions must perform bathing rituals to get rid of bad luck and open the ancient Qur'an; (2) Pilgrimage by local politicians in Bismo also has its own peculiarities. The motivation that drives them is not only religious enthusiasm but also secular impetus. Their visions on the Bismo Qur'an are intertwined between the view of the sacredness of the relics of the saints and the pragmatic view of positioning the Bismo Qur'an as an instrument to reserve their expectation.
\end{abstract}

Keywords: Living Qur'an-Hadith, pilgrimage ritual, ancient Qur'an manuscript, local politicians.

\begin{abstract}
Abstrak: Ziarah merupakan aktivitas yang sudah menjadi tradisi di kalangan umat Islam di Jawa. Salah satu destinasi penting yang banyak dikunjungi adalah desa Bismo. Di desa tersebut terdapat peninggalan para wali, salah satunya adalah manuskrip Alquran kuno yang diyakini sebagai tulisan tangan sunan Bonang (1465-1525). Tulisan ini mengungkap bagaimana sejarah dan praktik ritual ziarah di Bismo, dan bagaimana resepsi para politisi lokal terhadap ritual ziarah dan Alquran kuno di Bismo. Dengan menggunakan pendekatan antropologis, tulisan ini berkesimpulan bahwa (1) praktik ritual ziarah di Bismo termasuk unik, selain membaca bacaan dan doa sebagaimana yang dilakukan di tempat lain, peziarah yang mempunyai hajat khusus melakukan ritual mandi membuang sial dan membuka Alquran kuno; (2) Ziarah yang dilakukan para politisi lokal di Bismo juga memiliki
\end{abstract}


kekhasan sendiri. Motivasi yang mendorong mereka bukan hanya motivasi keagamaan namun juga motivasi sekuler untuk melancarkan cita-cita dan tujuan. Pandangan mereka terhadap Alquran Bismo berkelindan antara pandangan sakralitas terhadap peninggalan wali dan pandangan pragmatis memposisikan Alquran Bismo sebagai instrumen untuk menggapai hajat.

Kata kunci: Living Qur'an-Hadis, ritual ziarah, manuskrip Alquran kuno, politisi lokal.

\section{Pendahuluan}

Dalam bahasa Arab kata ziyarah secara etimologi mempunyai makna majī' ba'd al-abya' li ba'd mawaddat wa mahabbat (kedatangan seseorang kepada yang lain atas dasar rasa suka dan cinta). ${ }^{1}$ Namun dalam penggunaan keseharian masyarakat muslim, kata ziarah tidak hanya digunakan dalam kasus mengunjungi orang yang masih hidup saja, tapi juga digunakan untuk mengunjungi kuburan orang yang sudah meninggal atau tempat-tempat yang bersejarah.

Aktivitas ziarah jamak dipahami sebagai kegiatan mengunjungi suatu tempat yang dianggap oleh masyarakat mengandung keterkaitan dengan alam metafisik dan kadang juga mengandung unsur suci, keramat dan sakral. Praktik ziarah seperti ini bersifat universal, dilakukan oleh hampir semua pemeluk agama di seluruh belahan dunia, termasuk di Nusantara. Selain makam orang tua dan kerabat, tempat-tempat yang menjadi objek tujuan para peziarah umumnya adalah makam para tokoh, pejuang-shubadä, raja, para guru sufi, dan juga para wali. Kuburan para wali merupakan tempat istimewa bagi para peziarah. Tempat tersebut merupakan tempat vital karena diyakini bahwa orang yang berada di dalamnya adalah manusia suci yang diyakini mempunyai kelebihan dan kekuatan mistis (mystical power). ${ }^{2}$ Kajian akademik tentang ziarah para wali di dunia Islam telah dilakukan oleh Henri Chambert-Loir. Dia berhasil memberikan gambaran yang sangat jelas tentang tradisi ziarah makam para wali di Mesir, Sudan, Maroko, Afrika Barat, Iran, India, Pakistan, Banglades, Tiongkok, Turki, Asia Tengah, Balkan. Makam wali di Indonesia yang

\footnotetext{
1 Sirāj Jaylāni, "Ziyārah al-Uḍrị̣ah wa Athāruhā fì al-Mu'taqadāt al-Sha'bìyah: Ḍarih Sayyidi Yūsuf al-Sharif Namūdhajan” (Tesis, Universitas Aboe Bekr Belkaid, Fakultas Ilmu Humaniora dan Sosial, 2014/2015), 62.

2 Moh. Toriqul Chaer, "Aspek Religiousitas Masyarakat Peziarah Makam Syaykh Abdul Muhyi Pamijahan Tasikmalaya," dalam Maraji’: Jurnal Studi Keislaman, vol. 1, no. 2 (2015), 450.
} 
menjadi perhatian Chambert-Loir adalah Makam Sunan Gunung Jati dan Makam Kyai Telingsing Kudus. ${ }^{3}$

Masyarakat Muslim Jawa tradisional dikenal sebagai masyarakat yang gemar melakukan aktivitas ziarah. Selain secara individu, mereka melakukan ziarah secara berjamaah. Lokasi ziarah yang biasa dikunjungi adalah tempat-tempat yang dianggap keramat atau sakral, baik dalam bentuk makam atau petilasan para wali. Di antara petilasan yang sering dikunjungi para peziarah di Jawa dan dijadikan tempat tirakat adalah petilasan para wali yang berada di Desa Bismo, Kabupaten Batang. Tempat yang berlokasi di puncak gunung ini menyimpan beberapa petilasan bersejarah yang diyakini sebagai peninggalan sunan Bonang (1465-1525) dan Sunan Kalijaga (14501513). Salah satu peninggalan yang menarik adalah mushaf Alquran kuno yang diyakini sebagai tulisan tangan Sunan Bonang.

Pada umumnya umat Islam menjadikan Alquran sebagai mitra untuk mencari problem solving atas berbagai persoalan kehidupan yang dihadapi. Banyak ragam sikap maupun resepsi dalam memposisikan Alquran sebagai mitra untuk merespon berbagai problem tersebut. Sikap penerimaan dan resepsi umat Islam atas Alquran dapat digolongkan menjadi tiga bentuk, yaitu; resepsi hermeneutis, resepsi sosial-budaya, dan resepsi estetis. Resepsi jenis pertama lebih menekankan pada upaya untuk memahami kandungan Alquran, baik dalam bentuk penerjemahan maupun penafsiran. Sementara itu bentuk resepsi sosial-budaya dan estesis tidak hanya dipengaruhi anggapan Alquran sebagai petunjuk ( $b u d \bar{a})$ namun juga dipengaruhi oleh anggapan sakralitas dan kepentingan sosiologis dan psikologis yang sifatnya profan. ${ }^{4}$ Firman Tuhan tidak melulu dianggap mengandung fungsi ibadah dan peningkatan spiritualitas, namun juga diposisikan sebagai instrumen pijakan untuk tergapainya tujuan dalam kehidupan sosial. ${ }^{5}$

Gambaran seperti ini sangat nampak ketika melihat fenomena ziarah para politisi lokal ketika berinteraksi dengan mushaf Alquran

${ }^{3}$ Lihat Henri Chambert Loir dan Claude Guillot (eds.), Ziarah dan Wali di Dunia Islam, terj. Jean Couteau, Ari Anggari Harapan, Machasin, Andrée Feillard (Jakarta: Serambi, 2007), 9-18.

4 Ahmad Baidowi, "Resepsi Estetis Terhadap Alquran," dalam Dinamika Studi alQuran (Yogyakarta: Idea Press, 2009), 20.

${ }^{5}$ Mohammad Yahya, "Fungsi Simaan Alquran Bagi Santri Pondok Pesantren Sunan Pandanaran, Sleman, Yogyakarta," dalam Religia: Jurnal Ilmu-Ilmu Keislaman, vol. 20, no. 2 (2017), 221. 
kuno Bismo. Interaksi para politisi dengan mushaf Alquran Bismo tidak hanya dilandasi tujuan peningkatan spiritualitas keagamaan, melainkan juga untuk mencapai kepentingan-kepentingan sosiologis dalam kehidupan. Penafsiran atas ayat yang terbaca juga bukan saja penafsiran atas kandungan makna, namun lebih mengarah kepada pemaknaan simbolik sebagai isyarat petunjuk bagi langkah yang akan dilakukan. Interaksi dengan Alquran kuno Bismo merupakan satu paket ritual ziarah yang biasa disebut dengan 'ziarah menyingkap hajat', sehingga para peziarah harus melalui ritual-ritual pendahuluan seperti mandi dan ziarah di makam yang ada di sana.

Ritual ziarah dan resepsi masyarakat terhadap teks Alquran dapat dijumpai di banyak tempat, tidak hanya pada masyarakat Bismo. Namun resepsi terhadap manuskrip kuno Alquran Bismo yang menjadi bagian penting dalam ritual ziarah menyingkap hajat di Bismo ini terbilang unik. Di samping tujuan-tujuan profan yang diselubungi nuansa mistis yang melatari sebagaimana dipaparkan, interaksi peziarah dengan Alquran Bismo ini juga tetap dianggap masyarakat sebagai salah satu bentuk tradisi otentik yang diwariskan oleh generasi awal umat Islam, yaitu tradisi ziarah makam dan tabaruk.

Konstruksi pemikiran dan perilaku masyarakat yang termanifestasikan dalam bentuk ziarah dan ikhtiar menyingkap hajat melalui interaksi dengan manuskrip kuno Bismo, bukan hanya dapat dianggap sebagai fenomena living Qur'an namun ia juga merupakan bentuk ekspresi living Hadis. Kajian ini bukan hanya menguak resepsi politisi lokal terhadap Alquran kuno Bismo, namun juga menelisik ritual ziarah yang dilakukan oleh para politisi. Ziarah yang semula berfungsi sebagai sarana untuk mengingat kematian dan meningkatkan spiritualitas, pada gilirannya memiliki multi-fungsi dalam kehidupan praksis.

Tulisan ini secara spesifik bermaksud menjelaskan dua hal, yaitu: (1) Bagaimana sejarah dan praktik ritual ziarah menyingkap hajat melalui Alquran kuno di Bismo?; dan (2) Bagaimana resepsi politisi terhadap ritual ziarah tersebut? Tulisan ini menggunakan kerangka kajian living Qur'an-Hadis dengan metode etnografis yang bertujuan untuk mendeskripsikan realitas budaya yang terbentuk dan terinspirasi dari Alquran dan hadis berdasarkan pandangan natural subyek (native point of view). Pendeskripsian tersebut diuraikan secara detail dan tebal (thick description), bukan hanya sekedar memotret realita empiris saja 
tapi juga menyelami dan mendeskripsikan realitas simbol dan ide yang tersembunyi di baliknya.

\section{Alquran dan Hadis: Sumber Awal Ritual Ziarah}

Ziarah dalam artian mengunjungi tempat bersejarah dan disucikan disinggung beberapa kali dalam Alquran. Perjalanan Nabi Ibrahim dari Syam menuju Makkah untuk menghidupkan kembali Ka'bah, situs peribadatan manusia pertama, sebagaimana dikisahkan dalam surah Ibrahim merupakan salah satu bentuk ziarah di masa klasik. Demikian juga perjalanan Nabi Muhammad sewaktu isrä' dari Makkah menuju Bayt al-Maqdis di Palestina, sebagaimana disebut dalam surah al-Isrā’, salah satu tujuannya juga untuk menziarahi makam para Nabi sebelumnya yang dimakamkan di sana seperti Nabi Ibrahim, Nabi Ya'qūb dan Nabi Yūsuf.

Dalam QS. al-Tawbah [9]: 84, Allah melarang Nabi Muhammad menyalati orang-orang munafik yang meninggal, dan menziarahi kubur mereka (wa là taqum 'alà qabrib). Ayat ini menunjukkan larangan kepada Nabi menziarahi kuburan orang-orang munafik pada masa itu, dan secara implisit membolehkan atau bahkan mendorong untuk menziarahi orang-orang saleh pada waktu itu, yaitu para sahabatnya. Banyak kisah yang menceritakan nabi menziarahi para sahabat sebagaimana dijelaskan dalam hadis. ${ }^{6}$ QS. al-Mā’idah [05]: 35 juga ditengarai memberikan isyarat anjuran praktik ziarah. Kata "perantara" (al-wasilab) yang terdapat dalam ayat tersebut ditafsiri sebagai segala hal yang dapat mendekatkan diri kepada Allah, yaitu segala hal yang diberi kedudukan dan kemuliaan oleh Allah, termasuk para nabi, orang-orang saleh, dan para wali, baik ketika mereka masih hidup maupun setelah wafat. ${ }^{7}$

Hadis-hadis Nabi Muhammad juga banyak menyinggung mengenai ziarah kubur, menjelaskan aturan dan manfaatnya. Selain menyampaikan nasihat dan dorongan untuk melakukan aktivitas ziarah, Nabi Muhammad sendiri juga melakukan praktik ini. Tercatat dalam hadis bahwa beliau ketika kecil pernah diajak ziarah Ibunya ke makam ayahnya di dekat Madinah, dan ketika dewasa pernah menziarahi makam ibundanya, Āminah, yang di makamkan di Abwā'

\footnotetext{
${ }^{6}$ Lihat Yūsuf Khattāar Muhammad, Al-Mawsū'ah al-Yüsufiyan fì Bayān Adillat al-Süfìyah (Damaskus: Dār al-Taqwā), 313.

${ }^{7}$ Muḥammad b. 'Alawī al-Mālikī, Mafāhìm Yajỉb an Tuṣaḥaḥ (Beirut: Dār al-Kutub al'Ilmìyah, 2016), 118.
} 
daerah selatan Madinah. Selain menziarahi keluarga, Nabi juga diinformasikan menziarahi sahabat-sahabat utamanya yang gugur pada perang Badr dan Uhud dan juga para sahabat lainnya yang dikubur di pemakaman Baqī'.

Berpijak kepada teks primer keagamaan, para ulama kemudian menformulasikan konsep ziarah dalam warisan literatur mereka. Dalam kitab Nașầị̣ al-Tbäd misalnya, al-Nawawī Banten menuturkan ada empat macam motivasi orang melakukan ziarah kubur, yaitu: (1) Ziarah kubur dengan tujuan untuk mengingat kematian dan kehidupan akhirat. Ziarah dengan motivasi seperti ini hanya bisa dengan melihat kuburan atau komplek pemakaman tanpa harus mengetahui siapa yang dimakamkan di sana. Untuk menggapai tujuan ini juga, makam yang dilihat tidak harus makam orang Muslim, melainkan juga makam orang kafir, yang dapat menjadi sarana untuk mengingatkan seorang Muslim pada kematian dan kehidupan akhirat; (2) Ziarah kubur dengan tujuan untuk mendoakan orang yang diziarahi. Menurut al-Nawawī ziarah dengan tujuan seperti ini disunahkan bagi setiap orang Muslim. Kuburan yang diziarahi tentunya harus kuburan orang Muslim, baik keluarga sendiri atau orang lain; (3) Ziarah kubur dengan motivasi untuk tabarruk atau mengharap mendapat keberkahan. Ziarah dengan tujuan ini disunahkan dengan cara mengunjungi kubur orang-orang saleh; (4) Ziarah kubur dengan tujuan untuk memenuhi hak orang yang diziarahi, umpamanya berziarah ke makam orang tua. ${ }^{8}$

Literatur keislaman klasik juga mencatat praktik ziarah yang dilakukan oleh generasi awal Islam, sahabat, tabiin dan setelahnya. Mereka tidak hanya menziarahi keluarga, namun juga menziarahi makam-makam orang mulia, dengan tujuan untuk tabaruk. Bahkan untuk mengharap keberkahan seperti ini, generasi awal juga memperlakukan secara khusus segala peninggalan yang terkait tokoh yang disucikan tersebut. Al-Bukhārī (w. 256) dalam kitab al-Sahị̄h membuat satu pembahasan khusus mengenai hal ini dalam judul bab yang sangat panjang, yaitu bāb mā dhukira min dir' al-nabì salla Allāh 'alayh wa sallam wa 'asăh wa sayfih wa qadahih wa khätamih, wa mà ista'mala al-kbulafä' ba'dah min dhälik min mä lam yudhkar qismatuh, wa min sha'rih

\footnotetext{
${ }^{8}$ Muḥammad al-Nawāwī b. 'Umar al-Jāwī, Nașāiḥ al- Tbād Sharḥ al-Munabbihāt 'alā alIsti 'dàd li Yawm al-Ma'äd (Beirut: Dār al-Kutub al-'Tlmìyah, 2015), 67.
} 
wa na 'lih wa änìyatih min mä yatabarrak așhäbuh wa ghayrubum ba'd wafätih. ${ }^{9}$ Pada pembahasan ini, Imam al-Bukhārī memaparkan beberapa hadis dan juga äthär yang menceritakan tradisi para sahabat dan setelahnya dalam memperlakukan peninggalan-peninggalan Nabi setelah wafatnya, seperti baju perang, pedang, bejana, cincin, rambut, dan sandal dengan tujuan mengharap keberkahan. ${ }^{10}$

Generasi setelah sahabat juga melakukan hal yang serupa. Di antaranya adalah kisah mengenai Abū Haniffah $(80-150 \mathrm{H})$ saat berziarah ke Madinah, berdiri di hadapan makam Rasulullah lalu berkata,

"Hai orang yang termulia di antara manusia dan jin dan sebaikbaik makhluk, berilah aku kemurahanmu dan ridailah aku dengan ridamu. Aku merindukan kemurahan darimu, engkaulah satusatunya harapan Abū Hanīfah." 11

Kisah lainnya adalah kisah al-Shāfí̄ yang menziarahi makam Abū Hanīfah. Salah satu muridnya yang bernama 'Alī b. Maymūn, menceritakan bahwa dirinya pernah mendengar al-Shāfi' $\overline{1}(150-204 \mathrm{H})$ berkata:

"Aku selalu bertabaruk dengan Abū Ḥanīfah dan mendatangi makamnya dengan berziarah setiap hari. Jika aku mempunyai hajat, maka aku menunaikan salat dua rakaat, lalu aku datangi makam beliau dan aku memohon hajat itu kepada Allah di sisi makamnya, sehingga tidak lama kemudian hajatku segera terkabulkan." ${ }^{, 12}$

\section{Umat Islam dan Ragam Praktik Ritual Ziarah}

Dalam perspektif antropologi, ziarah merupakan aktivitas budaya yang dibangun di atas sebuah ide dan kepercayaan religi. Ziarah kepada orang tua dan kerabat dibangun atas dasar kepercayaan terhadap titah ilahi mengenai kewajiban berbakti kepada kedua orang

\footnotetext{
${ }^{9}$ Abū 'Abd Allāh Muhạammad b. Ismā'îl al-Bukhārī, Al-Jāmi' al-Saḩ̄ị, Vol. 2 (Kairo: al-Matba'ah al-Salafiyah, 1403 H.), 390-391.

${ }^{10}$ Kisah-kisah lain mengenai praktik tabaruk generasi awal Islam dapat dilihat dalam Hishām b. Muḥammad Ḥayjar al-Ḥasan̄i, Al-Tabarruk bi al-Ṣälihinn (Maroko: Dār alRashād al-Hadìthah, t.t.).

11 Muḥammad b. 'Alawī al-Mālikī, Al-Ziyārah al-Nabawìyah (Makkah: Maktabah alAwqāf wa al-Shu'ūn, t.th.), 56.

12 Abū Bakr Aḥmad b. 'Alī al-Baghdādī, Tārīkh al-Baghdād, Vol. 1 (Beirut: Dār alKutub al-'Ilmìyah, 1931), 123.
} 
tua (birr al-wälidayn), dan berbuat baik kepada sesama kerabat (al-iḥsān bi al-qurbā). Aktifias ini juga didasari motivasi keyakinan bahwa orang yang memperhatikan orang tua dan kerabatnya baik semasa hidupnya atau setelah wafat akan mendapatkan kesuksesan di dunia dan akhirat. Kesusahan dan rintangan hidup diharapkan terurai dengan melakukan aktivitas tersebut.

Sementara itu, menziarahi makam yang dinilai suci dan sakral juga dibangun atas dasar ide dan keyakinan religi tertentu. Penilaian bahwa di suatu makam terdapat roh para tokoh dan leluhur suci yang harus dihormati, diingat jasanya dan bahkan dijadikan perantara dalam berdoa untuk mendapatkan keberkahan, merupakan ide-keyakinan yang mendorong timbulnya aktivitas budaya tersebut.

Dalam tradisi Islam, orang yang meninggal harus dikuburkan di dalam liang lahat. Wujud kebendaan tanah yang di dalamnya ada jasad orang yang sudah meninggal biasa disebut dengan pekuburan atau makam. Berdasarkan kategori pandangan terhadap orang yang disemayamkan dalam kubur, area pemakaman dapat dikelompokkan ke dalam dua kategori, yaitu (1) pemakaman umum, yang berisi makam-makam masyarakat pada umumnya; (2) pemakaman khusus, yaitu makam yang oleh masyarakat dinilai suci dan sakral seperti makam para wali atau makam para raja dan bangsawan. Pemakaman umum biasanya diziarahi oleh para saudara dan anak cucu. Sedangkan pemakaman khusus banyak dikunjungi oleh masyarakat umum, bahkan oleh orang-orang yang berasal dari luar daerah tersebut. Pandangan suci terhadap makam tentunya tidak lepas dari orang yang dimakamkan di dalamnya. Orang-orang tersebut pada masa hidupnya dinilai mempunyai kelebihan dalam masalah keagamaan maupun sosial. Mudjahirin Thohir mengistilahkan orang-orang yang ditawasuli dan kadang juga diziarahi dengan sebutan istilah cultural hero, yaitu tokoh-tokoh spiritual yang dinilai masyarakat mempunyai peran penting pada masanya. ${ }^{13}$

Fenomena ziarah makam para wali dan orang saleh merupakan fenomena budaya yang sudah mengakar lama di sebagian besar dunia Islam. Islam yang mulanya di Makkah-Madinah menyebar ke berbagai belahan dunia melalui upaya para pendakwah yang kemudian menetap dan meninggal di berbagai penjuru. Makam-makam mereka kemudian dirawat, dikenang, diziarahi sehingga membentuk kisah-kisah lisan,

13 Mudjahirin Thohir, Orang Islam Jawa Pesisiran (Semarang: Fasindo Press, 2006), 166-167. 
keyakinan dan pandangan yang terus terwariskan dari generasi ke generasi sehingga membentuk memori kolektif bahwa kuburan tersebut adalah kuburan orang suci. ${ }^{14}$

Area kuburan para wali biasanya juga didukung dengan model arsitektur khas yang memancarkan kewibawaan dan sakralitas. Di daerah Timur Tengah, kubah yang dibangun di atas kuburan para wali menjadi sebuah ciri khas, sekaligus memberi aura sakralitas tersendiri. Di daerah Syam, misalnya, kuburan para Nabi, wali dan ulama mendapat perhatian khusus di kalangan masyarakat, di mana di atasnya dibangun kubah dan dijadikan tempat ziarah. Di antaranya adalah makam Nabi Yahyyā, Nabi Ayyūb, Nabi Șāliḥ, Nabi Yūnus, Nabi Ya'qūb, Nabi Yūsuf, Nabi Mūsā dan Nabi Hūd. ${ }^{1{ }^{\prime}}$

Di Mesir juga tidak jauh berbeda. Banyak kuburan para sahabat, ulama, dan para wali yang dibangun dengan arsitektur yang megah dan dijadikan tempat tujuan untuk melakukan ritual ziarah. Di antaranya adalah kuburan sayyid Husayn (cucu Nabi), sahabat Abū alDardā', sayyidah Zaynab, sayyidah Nafīsah, Imam al-Shāfi'̄̄, sayyid Badawī dan lain sebagainya. Biasanya di samping kuburan tersebut juga dibangun masjid. Begitu juga di Maroko banyak dijumpai bangunan pemakaman para wali yang ramai dikunjungi para peziarah, seperti makam Imam al-Jazūili. ${ }^{16}$

Kondisi tersebut tidak jauh berbeda dengan di Indonesia, khususnya di Jawa. Tempat pemakaman yang menjadi tujuan peziarah adalah makam-makam yang dianggap mempunyai karämah, sehingga menurut Nur Syam, ziarah bagi masyarakat Islam Jawa mempunyai dimensi emosi keagamaan dan juga keyakinan. ${ }^{17}$ Bagi masyarakat Pesisir Jawa, makam bukan hanya dipahami sekedar tempat menyimpan mayat, namun juga menjadi lokus tempat berkumpul, mamanjatkan doa dan memburu berkah. Di antara makam yang disebut Syam sebagai makam keramat di Pesisir Utara Jawa Timur adalah komplek pemakaman Sunan Ampel, makam Putri Suwari di Leran, makam Malik Ibrahim dan Giri di Gresik, Sunan Drajat di Paciran dan Sunan Bonang di Tuban. ${ }^{18}$

\footnotetext{
${ }^{14}$ Jaylānī, "Ziyārah al-Uḍihịah,” 16.

15 Ibid., 70-71.

16 Ibid., 72.

${ }^{17}$ Nur Syam, Madz̧ab-madz̧ab Antropologi (Yogyakarta: LKIS Group, 2012), 117.

${ }^{18}$ Nur Syam, Islam Pesisir, (Yogyakarta: LKIS, 2005), 140.
} 
Di wilayah Jawa khususnya, aktivitas mengunjungi kuburan disebut dengan beberapa istilah, yaitu ziarah, nyekar dan sowan. Istilah ziyarah merupakan istilah berbahasa arab yang sudah diserap dalam bahasa Indonesia dan Jawa. Kata ini mengandung maksud mengunjungi, khususnya mengunjungi makam. Sedangkan kata nyekar dari bahasa jawa yang mempunyai arti menabur bunga di atas pusara makam yang dikunjungi. Sementara itu sowan juga bahasa Jawa yang berarti mengunjungi seseorang baik yang masih hidup atau yang sudah meninggal yang mempunyai status sosial yang lebih tinggi. ${ }^{19}$

Woodward mengamati adanya perbedaan pola tradisi ziarah kubur antara ziarah makam yang dikeramatkan pada umumnya dengan ziarah ke makam keluarga keraton Yogyakarta. Untuk kategori yang pertama, para peziarah pada umumnya berharap mendapatkan berkah untuk mengatasi ragam permasalahan hidup yang dialami, di samping juga sebagian berharap untuk meningkatkan spiritualitas dan kedekatan dengan Tuhan. Sementara itu, para peziarah ke makam keraton sangat patuh dengan aturan yang ditetapkan utamanya terkait dengan hari dan jam berziarah. ${ }^{20}$ Mirip dengan kajian Woodward, Fikria Najitama juga mengamati bahwa tempat-tempat keramat yang diziarahi oleh para peziarah di Kebumen dapat dikelompokkan menjadi dua yaitu pertama makam para wali yang merupakan tokoh agama dan disebut sebagai makam suci. Sedangkan yang kedua adalah makam para priyayi yang dulunya adalah tokoh elit masyarakat, makam seperti ini dapat dikategorikan sebagai makam resmi. ${ }^{21}$

Kasus yang unik adalah kasus makam Sunan Tembayat. Sebagian menganggapnya sebagai wali sedangkan yang lain menganggapnya sebagai priayi. Jamhari dalam penelitian mengenai tradisi ziarah di makam Sunan Tembayat menemukan perbedaan model ziarah tergantung dengan pandangan peziarah terhadap makam tersebut. Sebagian menganggap bahwa Sunan Tembayat adalah punden (tokoh awal yang membuka daerah tersebut). Sedangkan yang lain menganggap bahwa Sunan Tembayat adalah salah satu wali yang ada di bumi Jawa. Perbedaan pandangan ini mempengarui motivasi para

19 Jamhari, "In the Center of Meaning: Ziarah Tradition ini Java," dalam Studia Islamika, vol. 7, no. 1 (2000), 55.

${ }^{20}$ Mark R. Woodward, Islam Jawa, Kesalehan Normatif Versus Kebatinan, Terj: Hairus Salim HS (Yogyakarta: LKIS, 2008), 258-268.

${ }^{21}$ Fikria Najitama, "Ziarah Suci dan Ziarah Resmi: Makna Ziarah pada Makam Santri dan Makam Priyayi”, dalam IBD A': Jurnal Kajian Islam dan Budaya, vol. 11, no. 1 (2013), 21. 
peziarah ketika mendatangi makam tersebut. Atas dasar itu, peziarah di makam Sunan Tembayat dapat dikelompokkan ke dalam dua kategori, yaitu ziarah cara orang Islam dan ziarah cara orang Jawa. Ziarah yang pertama dilakukan dengan membaca Alquran, tahlil dan zikir, sedangkan model kedua dengan cara melakukan tapa dan meditasi. Istilah yang digunakan oleh dua kelompok ini juga berbeda, yang pertama menggunakan istilah ziarah, sedangkan yang kedua menggunakan istilah nyekar, atau sowan. ${ }^{22}$ Jamhari juga menjelaskan bahwa perbedaan ini memberi pengaruh kepada tujuan yang ingin diperoleh setelah ziarah. Sebagian mengharapkan keberkahan dari Tuhan, yaitu kebaikan-kebaikan yang sifatnya keagamaan seperti ketenangan jiwa dan tertuntunnya hidup, serta pahala ukhrawi. Sedangkan sebagian yang lain mengharapkan perolehan yang sifatnya duniawi, seperti mencari kekayaan, menarik lawan jenis, sukses dalam bisnis ataupun belajar dan lainnya. ${ }^{23}$

Ziarah bukan hanya sekedar aktivitas fisik yang hampa makna. Bagi para pelaku, menziarahi makam keramat mempunyai bermacammacam makna. Menurut Jamhari, aktivitas ziarah bukan hanya mempunyai makna keagamaan, namun juga mengandung makna sosial juga politis. ${ }^{24}$ Bahkan di sebagian daerah, seperti di Afrika Utara, ziarah menjadi sarana untuk mengukuhkan identitas jalur sanad keilmuan seseorang. Eickelman dalam penelitiannya di Maroko, sebagaimana dikutip oleh Jamhari, mengamati bahwa ziarah merupakan proses penajaman pandangan religiositas, gerakan spiritual untuk memperbarui dan meningkatkan pemahaman keagamaan, dan simbol gerakan spiritual: pergerakan dari jiwa yang kotor menuju jiwa yang bersih. ${ }^{25}$ Sementara itu Nafīsah Duwaydah menyimpulkan bahwa ziarah yang dilakukan oleh umat Islam ke makam para wali di Aljazair mempunyai beberapa makna dan tujuan, yaitu (1) Tujuan pengobatan dan kesehatan; (2) Tujuan sosial untuk membangun jaringan, solidaritas dan kohesifitas; (3) Tujuan psikologi dan kejiwaan, untuk mendapatkan ketenangan dan ketentraman; dan (4) Tujuan keagamaan, untuk mengingkatkan spiritualitas dan kedekatan dengan Tuhan. $^{26}$

\footnotetext{
22 Jamhari, "In The Center of Meaning”, 67.

${ }^{23}$ Ibid., 87.

${ }^{24}$ Ibid., 55-56.

25 Ibid., 67.

${ }^{26}$ Nafīsah Duwaydah, "al-Mu'taqadāt wa al-Ṭuqūs al-Khāṣṣah bi al-Uḍrihah fì alJazā’ir Khilāl al-Fatrah al-'Uthmānīyah” dalam Jurnal Insāniyāt, vol. 68 (2015), 11-34.
} 
Selain bersifat fungsional, ziarah juga kadang menjadi medan konflik wacana perdebatan keagamaan. Di Jawa misalnya tradisi ziarah yang kadang bercampur dengan tradisi-tradisi pra Islam menjadikan praktik tersebut sering kali dipertanyakan keotentikan dan kelegalannya. Sebagian pihak meyakini bahwa ziarah yang sudah mentradisi di Jawa dengan tawasul dan tabaruknya merupakan implementasi kreatif dari ajaran Alquran dan hadis, dan juga sebagai bentuk kelanjutan dari tradisi turun menurun yang dilakukan oleh generasi Islam awal hingga masa kewalian di Jawa. Sementara itu sebagian pihak yang lain menyatakan bahwa model ziarah tinggalan Walisongo di Jawa merupakan bentuk sinkretik yang mengarah kepada tindakan heretic, sehingga proses islamisasi dan purifikasi perlu dilakukan. $^{27}$

\section{Desa Bismo dan Peninggalan Para Wali}

Bismo adalah salah satu Desa di Kecamatan Blado Kabupaten Batang yang mempunyai luas wilayah 528,82 hektar. Desa Bismo berada di daerah pegunungan dengan ketinggian \pm 1.100 meter di atas permukaan laut (mdpl) dan curah hujan $\pm 2.052 \mathrm{Mm} /$ th dengan suhu udara dingin rata-rata $18-26^{\circ}$ celcius.

Sebelum disebut desa Bismo, daerah tersebut merupakan hutan belantara dan belum dihuni oleh manusia satupun. Tidak ada informasi tertulis mengenai awal mula desa ini, namun berdasarkan cerita yang beredar di masyarakat, desa Bismo merupakan daerah yang pernah disinggahi oleh dua wali kesohor di Jawa saat melakukan perjalanan dakwah, yaitu Sunan Bonang (1465-1525) dan Sunan Kalijaga (1450-1513). Dua tokoh tersebut datang di Bismo dan berjumpa dengan beberapa wali lain yaitu Shaykh Jamsari, Shaykh Rahimudin, dan Shaykh Nur Khalim.

Dikisahkan para wali tersebut mengadakan pertemuan untuk menetapkan daerah Bismo sebagai pedukuhan dan mengangkat Shaykh Jamsari sebagai pimpinan yang diangkat untuk menjaga daerah tersebut. Setelah dibuka, mulailah penduduk berdatangan untuk hidup di daerah tersebut. Nama Bismo sendiri berawal dari kisah Shaykh Jamsari melakukan perjalanan mengelilingi daerah itu. Dia menemukan lima mata air di daerah tersebut. Dalam istilah Jawa disebut mbese ono limo (sumbernya ada lima), sehingga daerah itu disebut oleh Shaykh Jamsari dengan sebutan Bismo. Para wali

${ }^{27}$ Jamhari, “In The Center of Meaning," 56-57. 
tersebut hanya singgah untuk berdakwah sehingga penduduk setempat menyebutnya dengan $W$ ali Sowan. 28 Para wali tersebut memang tidak menetap di daerah Bismo namun mereka meninggalkan petilasan yang dianggap bersejarah dan dikeramatkan oleh masyarakat. Masyarakat sekitar menyebut tempat petilasan bersejarah tersebut dengan sebutan makam Sunan Bonang dan Sunan Kalijaga.

Peninggalan penting dan bersejarah di desa Bismo yang hingga saat ini dikeramatkan oleh masyarakat adalah (1) lima sumber mata air; (2) masjid; (3) kopiah kuno; dan (4) mushaf Alquran kuno. Dua peninggalan pertama dikaitkan sebagai petilasan Sunan Kalijaga. Sedangkan dua peninggalan yang lain, yaitu kopiah dan mushaf Alquran diyakini sebagai petilasan Sunan Bonang.

Lima sumber mata air yang sangat jernih dan melimpah di Bismo merupakan petilasan pertama yang penting bagi masyarakat Bismo. Lima mata air tersebut adalah (1) mata air Mubal, (2) mata air Makandowo, (3) mata air Pucung. (4) mata air Lingsar dan (5) mata air Dadapan. ${ }^{29}$ Sumber mata air tersebut menjadi sumber kehidupan yang sangat bermanfaat bagi masyarakat sekitar baik untuk kebutuhan keseharian atau untuk perkebunan dan pertanian. Bahkan sumber mata air ini digunakan PDAM Kabupaten Batang untuk melayani kebutuhan air masyarakat Kabupaten Batang dan Kota Pekalongan.

Selain sebagai penyedia air, mata air tersebut juga diyakini keramat oleh masyarakat, terutama mata air Mubal karena di sana terdapat sumber air yang disebut dengan Tuk Limo. Sumber air ini oleh masyarakat juga terkenal dengan sebutan telaga al-Kautsar, sebagaimana dikatakan oleh Suwanto:

"Di Telaga al-Kautsar Sunan Kalijaga mengambil air wudu kemudian salat di atas batu. Di Bismo ada dua tempat yang digunakan Sunan untuk bersujud, yaitu di masjid dan di mata air ini." 30

Sejarah lisan ini menyebabkan masyarakat dan para peziarah meyakini bahwa air tersebut penuh berkah dan dapat dijadikan sarana untuk penyembuhan penyakit. Hampir dipastikan setiap peziarah akan melakukan cuci muka, berwudu atau membawa air dari sumber mata

\footnotetext{
${ }^{28}$ Wawancara dengan H. Turyono (Juru Kunci Makam Bismo) pada 16 Juli 2019.

29 Ibid.

${ }^{30}$ Wawancara dengan Suwanto (Warga Bismo) pada 20 Juli 2019.
} 
air tersebut untuk kemudian didoakan di makam wali dan dibawa pulang untuk "ngalap berkah".

Tidak jauh dari sumber air Tuk Limo, sekitar perjalanan 300 meter terdapat peninggalan penting kedua di Bismo, yaitu bangunan masjid kuno yang diyakini didirikan oleh para $W$ ali Sowan. Masjid yang diberi nama al-Huda ini dalam penuturan masyarakat merupakan salah satu dari 3 masjid yang dibangun para wali, yaitu di Bismo, di Wonobodro, dan di Gringgingsar. Turyono menuturkan:

"Desa Bismo dikenal lebih tua dari Wonobodro. Ini bukan karena sosok kiai atau wali yang tinggal di desa Bismo. Tapi karena keberadaan masjidnya, yaitu masjid yang pertama dibangun adalah Masjid al-Huda (di Bismo), selanjutnya Wonobodro dan disusul dengan masjid Wonotunggal, untuk tahun berapanya tidak diketahui secara pasti, yang jelas yang mendirikan, yang kami yakini, adalah Sunan Bonang dan Sunan Kalijaga." 31

Konstruksi masjid menggunakan kayu, layaknya masjid-masjid masa itu. Terdapat empat tiang kayu penyangga bangunan, dan juga terdapat dudukan kayu di bagian atasnya yang menjadi penyangga atap. Selain difungsikan sebagai tempat ibadah salat dan ritual kegamaan lainnya, masjid ini juga dianggap mistis. Dalam pandangan sebagian masyarakat tiang masjid terebut mengandung makna dan fungsi tersendiri. Tiang di sebelah barat laut yang dikatakan dibuat Sunan Kalijaga disebut dengan soko berkah (tiang yang berkah). Tiang yang berada di barat daya dianggap mempunyai tuah untuk meraih pangkat. Sedangkan yang berada di sebelah tenggara diyakini mengandung tuah untuk kekuatan, dan yang di sebelah timur laut untuk mencari jodoh. Dari keempat tiang tersebut, tiang Sunan Kalijaga yang banyak mendapat perhatian para peziarah, di samping karena dianggap sebagai buatan Sunan Kalijaga, tiang ini juga dihiasi dengan ornamen ukiran. Sebagian peziarah memanjatkan doa kepada Allah di dekat tiang-tiang ini.

Peninggalan penting berikutnya adalah kopiah. Konon kopiah tersebut adalah kopiah yang pernah dipakai Sunan Bonang waktu datang di desa Bismo bersama Sunan Kalijaga untuk menyebarkan Islam. Peci Sunan Bonang ini terbuat dari anyaman akar-akaran. Banyak yang meyakini jika peziarah bisa memakai kopiah tersebut, akan dimudahkan dan disegerakan pergi ke kota suci untuk

${ }^{31}$ Wawancara dengan H. Turyono (Juru Kunci Makam Bismo) pada 16 Juli 2019. 
menunaikan haji ke Baitullah. Namun jika peci tersebut tidak berkenan atau tidak pas ketika dipakai sehingga tidak bisa diletakkan di kepala, maka ini menjadi pertanda orang tersebut masih jauh citacitanya untuk ke Baitullah dan bisa juga tidak ada takdir untuk bisa pergi haji.

Peninggalan keempat adalah mushaf Alquran kuno Bismo. Ini merupakan peninggalan yang khas dan istimewa di Bismo. Mushaf ini diyakini sebagai tulisan tangan Sunan Bonang. Alquran kuno Bismo dianggap oleh banyak kalangan adalah Alquran keramat, karena Alquran tersebut hasil tulisan asli Sunan Bonang. ${ }^{32}$ Alquran ini diyakini memiliki keajaiban, sebab ia dapat menyingkap potret diri seseorang. Mengenai asal-usul tulisan Alquran ini Turyono juru kunci petilasan mengungkapkan:

"Alquran tersebut awalnya masih bentuk lembaran-lembaran, ada yang tergulung atau terlipat. Kertasnya berserakan dan tercampur dengan kertas-kertas lain di gudang Masjid al-Huda. Sebagian kertas yang berserakan tersebut rusak karena dimakan serangga atau tikus dan usang termakan waktu. Hal itu terjadi karena tidak ada yang berani menyentuh apalagi merapikan dan memilah-milah kertas tersebut. Hingga pada akhirnya saya (Turyono) pada tahun 1987-an memberanikan diri untuk mengumpulkan, menyusun lembaran-lembaran yang berserakan tadi, dan memilah-milah tulisan yang memang bagian dari mushaf Alquran. Setelah saya menyusunnya dapat dua tumpukan, lalu malamnya saya mimpi didatangi sosok laki-laki yang berjubah putih bersih yang mengaku bernama Darno dari desa Pokoh (di sana terdapat makam Shaykh Abdul Jabbar cucu murid dari Sunan Bonang dan Sunan Kalijaga). Dia memberi pesan singkat "jogo lan rumat Alquran kuwi seng apik, insya Alläh ono gunane" (jaga Alquran tersebut dengan baik, insya Allah ada gunanya)." 33

Gambar: Alquran Kuno Bismo dan Kopyah

\footnotetext{
32 Wawancara dengan H. Turyono (Juru Kunci Makam Bismo) pada 22 Juli 2019.

${ }^{33}$ Ibid.
} 


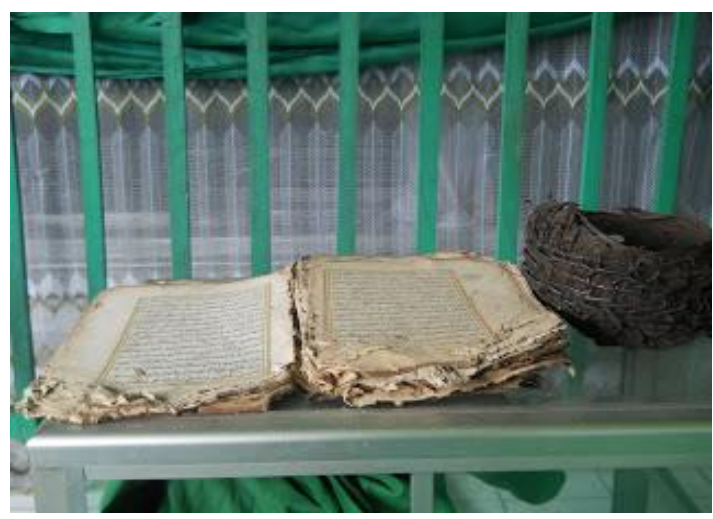

\section{Ziarah Bismo: Ragam Ritual dan Makna}

Secara antropologis, tradisi ziarah tidak dapat dilepaskan dari tiga unsur pembentuknya, yaitu (1) al-muqaddas; (1) al-ustūrah; dan (3) altuquis. Unsur pertama adalah sesuatu yang dianggap suci dan sakral. Para ulama atau wali yang dimakamkan dan juga peninggalan serta petilasan mereka merupakan benda-benda yang dianggap suci dan sakral oleh para peziarah. Unsur kedua adalah kisah turun temurun baik tertulis maupun lisan yang menceritakan seputar al-muqaddas. Kisah mengenai sejarah dan juga kadang sisi magis dan suprarasional ini semakin menambah tebal nuansa sakralitas. Sedangkan unsur ketiga adalah ritual yang dijadikan sarana untuk melakukan interaksi magis dengan benda yang disucikan tersebut. Pembacaan mantra, doa ataupun lantunan ayat-ayat suci serta prosedur protokoler tertentu merupakan di antara bentuk ritual pengagungan yang dianggap suci. ${ }^{34}$

Tradisi ziarah di Bismo memenuhi tiga unsur ini. Petilasan dan peninggalan para wali yang ada di sana dianggap suci (al-muqaddas) oleh masyarakat. Unsur ini juga ditopang dengan kisah (al-ustūrah) yang secara turun menurun mempertebal kesan kesucian dan kesakralan tempat tersebut. Sedangkan al-tuquis atau ritual, terlihat pada tata cara ziarah yang secara umum tidak jauh berbeda dengan cara ziarah di tempat lain, namun terdapat ritual khas saat ziarah

\footnotetext{
34 Thiyāqah al-Ṣadīq, "Al-Muqaddas wa al-Qabīlah: al-Mumārasah al-Iḥtifālīyah ladā al-Mujtama‘āt al-Quṣūrīyah bi al-Janūb al-Gharbī al-Jazā’irī," (Disertasi, Universitas Wahran Aljazair, Fakultas Ilmu Sosial, 2014), 85-92.
} 
dimaksudkan untuk menyingkap hajat tertentu, yaitu ritual pembacaan Alquran Bismo yang tidak dijumpai di tempat lain.

Ziarah merupakan aktivitas keagamaan dan sekaligus aktivitas sosial yang mentradisi khususnya di dunia Islam, termasuk di Nusantara. Selain makam keluarga, makam para tokoh atau yang dianggap punya jasa seperti para wali, ulama, bangsawan, pahlawan, juga menjadi tujuan para peziarah. ${ }^{35}$ Para peziarah pergi ke tempattempat keramat dengan motivasi dan harapan yang berbeda-beda, di antaranya untuk "ngalap berkah" dan terkabulnya hajat, tidak terkecuali para peziarah di makam Bismo.

Terdapat waktu-waktu favorit untuk menziarahi komplek makam Bismo. Tidak seperti di tempat lain yang biasanya ramai pada hari Jumat Kliwon, pemakaman Bismo justru ramai dikunjungi pada Kamis Pahing malam Jumat Pon. Even tahunan juga menjadi pilihan para peziarah untuk mendatangi Bismo yaitu setiap tanggap 12 Muharram. Selain hari-hari itu, tempat ini juga ramai diziarahi terutama pada hari libur umum baik hari Jumat atau Ahad, dan hari besar Islam lainnya. Bukan hanya penduduk sekitar yang datang, tapi juga para peziarah dari luar kota seperti Pekalongan, Kendal, Pemalang, Tegal dan lainnya.

Para peziarah di Bismo secara umum dapat dikelompokkan ke dalam dua kategori. Pertama adalah para peziarah yang tidak mempunyai hajat khusus. Ritual yang dilakukan oleh peziarah kelompok ini biasanya mengunjungi petilasan yang ada, yaitu sumber mata air dan masjid. Di samping menikmati keindahan dan keasrian pegunungan, mereka juga melantunkan surah Yāsīn dan tahlil serta memanjatkan doa di tempat-tempat tersebut.

Kelompok kedua adalah para peziarah dengan hajat khusus, baik hajat keagamaan, keluarga, ekonomi maupun politik, seperti ingin lekas mendapat jodoh, pergi haji, lancar usaha bisnisnya atau untuk melancarkan proses menduduki jabatan tertentu semisal kepala desa, anggota legislatif atau yang lainnya. Ritual yang dilakukan oleh

35 M Misbahul Mujib, "Fenomena Tradisi Ziarah Lokal Dalam Masyarakat Jawa: Kontestasi Kesalehan, Identitas Keagamaan Dan Komersial," dalam IBD A': Jurnal Kajian Islam Dan Budaya, vol. 14, no. 2 (2016), 212. 
peziarah kelompok kedua ini sedikit berbeda dibanding yang pertama. Mula-mula mereka harus menghubungi juru kunci untuk memandu ritual yang akan dilakukan. Sebelum memasuki area masjid al-Huda, peziarah dianjurkan terlebih dahulu mandi di "tuk limo" yang jaraknya tidak terlalu jauh dari masjid. Air "tuk limo" ini dipercaya membawa berkah dan memiliki banyak khasiat. Kemudian mereka memasuki area masjid tepatnya ke tempat penyimpanan kopiah dan mushaf Alquran Bismo. Dengan dipandu juru kunci, mereka berdoa di petilasan makam Sunan Bonang dan Sunan Kalijaga, kemudian mereka menyampaikan hajatnya kepada juru kunci. Di sinilah akan dimulai prosesi pembukaan Alquran Kuno Bismo antara peziarah yang mempunyai hajat dan juru kunci. Ketika hendak membuka mushaf Alquran, peziarah dan juru kunci secara bersama membaca syahadat, istigfar, selawat, umm al-kitāb (al-fātiḥah), masing-masing tiga kali. Setelah pembacaan selesai, juru kunci berdoa dalam hati yang isinya "Ya Allab berikanlab petunjuk dan jalan keluar agar hajat peziarab ini terkabul' dan peziarah dipersilahkan untuk membuka Alquran Kuno Bismo secara bebas dan spontan, lalu menarik lembaran ayat Alquran yang dipilihnya. Peziarah diminta untuk mengangkat lembar Alquran ke atas kepalanya untuk menerawang dan melihat gambar apa yang nampak dalam pandangan peziarah. Biasanya gambar yang terlihat adalah gambar macan berdiri di tahta lengkap dengan tombak disampingnya, atau macan "jengking" (merunduk), dan ada juga yang tidak melihat gambar apapun saat menerawang lembaran mushaf tersebut. Gambar-gambar abstraksi ini kemudian ditafsiri oleh juru kunci.

Kemudian peziarah diminta untuk membaca ayat-ayat yang berada dalam lembaran yang diambil tersebut. Lalu juru kunci mengartikan ayat itu, untuk kemudian ditafsirkan dan dikaitkan dengan hajat peziarah. Turyono sang juru kunci mengungkapkan:

"Ketika peziarah membaca ayat-ayat dari Alquran Kuno Bismo, saya hanya berdoa kepada Allah di hati untuk diberikan petunjuk dan jalan keluar kepada orang-orang yang membutuhkannya. Bila prosesi sudah selesai, saya hanya membaca arti ayat-ayat yang dibaca lewat Alquran terjemahan, setelah itu saya menjelaskan dan menerangkan sesuai krenteg (bisikan) dan arahan hati saya. Saya tidak pernah mengenyam pendidikan pesantren, biasanya muncul perasaan kuat di hati saya apakah hajat peziarah akan berhasil atau tidak. Bila krenteg hati mengatakan ini baik itu artinya hajatnya akan terkabul, dan jika krenteg hati tidak nyaman atau negatif, maka 
peziarah lebih baik jangan diteruskan bila mengikuti kontes Pilkades, Bupati, anggota Dewan dari pada nanti akan rugi secara finansial dan rugi waktu." 36

Peziarah yang mempunyai maksud khusus selalu di dampingi oleh juru kuci, yang bernama Haji Turyono yang tinggalnya tidak jauh dari masjid. Dia melayani 24 jam bila ada peziarah yang membutuhkannya. Haji Turyono menceritakan cerita awalnya menjadi juru kunci di petilasan Bismo tersebut:

"Dulu saya punya masalah ekonomi, lalu saya membuka Alquran tersebut 3 kali, dan tak disangka saya dapati tiga kali ayat yang sama yang intinya harus bersyukur dengan nikmat yang diberikan oleh Allah. Setelah itu, pada malam harinya, saya tidur di kamar bersama istri dengan kondisi rumah terkunci. Saya mimpi tapi rasanya setengah sadar ditemui seseorang berbadan besar tapi agak gelap sambil berjalan mundur sembari menyodorkan tangannya dengan mengucapkan "aku disarutangi satus". Lama-lama suara itu hilang bersamaan dengan tubuhnya. Saya bangun dan segera mengecek pintu rumah. Saya dapati pintu rumah masih dalam keadaan yang sama, terkunci. Langsung paginya saya memutuskan untuk sowan ke guru saya Mbah Kyai Su'udi Sipacar Kec. Tirto Kota Pekalongan. Saya menceritakan keadaan tersebut kepada beliau, lalu beliau merespon dengan cepat dengan mengatakan "saiki dino Rabu Pabing kan? Wes saiki poso wae, arti kata "aku disarutangi satus" yaitu "Gulune disat, wetenge ditus." Posomu mulai (1) Rabu Pabing, Kamis Pon, Jumat Wage; (2) Rabu Wage, Kamis Kliwon, Jumat Legi; (3) Rabu Legi, Kamis Pabing, Jumat Pon. Puasa iku jumlahe 9 hari selama satu bulan dimulai dino Rabu Pabing. Terus iku kok jalani salama 40 kali" (sekarang hari Rabu kan? Sudah sekarang puasa saja, arti kata "aku dibayarkan hutangnya serratus" adalah "lehernya dikeringkan, perutnya dikosongkan." Puasamu mulai (1) Rabu Pahing, Kamis Pon, Jumat Wage; (2) Rabu Wage, Kamis Kliwon, Jumat Legi; (3) Rabu Legi, Kamis Pahing, Jumat Pon. Puasa tersebut berjumlah 9 hari selama satu bulan dimulai hari Rabu Pahing, dan itu harus kami lakukan selama 40 hari). Dari hasil sowan tersebut akhirnya saya memutuskan untuk mengikuti nasehat beliau dengan puasa terus menerus hingga 15 tahun. Setelah puasa selesai dengan sempurna, tanpa disadari saya ada perasaan yang kuat, yakin dan mantab untuk menyampaikan

${ }^{36}$ Wawancara dengan H. Turyono (Juru Kunci Makam Bismo) pada 22 Juli 2019. 
kepada peziarah bila ada peziarah yang akan melakukan ritual menggunakan Alquran Kuno Bismo." ${ }^{37}$

\section{Politisi Lokal, Ziarah dan Alquran Bismo}

Komplek Bismo menjadi daya tarik tersendiri bagi banyak kalangan baik rakyat biasa, pedagang, pejabat atau calon pejabat dengan tujuan dan maksud yang beragam. Banyak kajian yang menyimpulkan bahwa ziarah yang dilakukan oleh masyarakat Jawa tidak melulu dimotivasi oleh kepentingan religius untuk mendekatkan diri kepada Allah, namun kadang juga disisipi kepentingankepentingan sekuler untuk menggapai target dan cita-cita kehidupan. ${ }^{38}$ Ini juga terjadi pada praktik Ziarah di Bismo. Selain tujuan wisata, meningkatkan spiritualitas, mengekpresikan kecintaan kepada para wali, sebagian peziarah di Bismo juga mempunyai tujuan khusus untuk menyingkap hajat melalui Alquran kuno Bismo dengan bimbingan juru kunci.

Haji Turyono selaku juru kunci menjelaskan:

"Saat ini Alquran kuno Bismo sering dipakai untuk istikharah. Jika ingin melihat riwayat hidup ya silahkan para peziarah membuka Alquran kuno tersebut yang ada di masjid al-Huda, tapi tidak boleh berbohong alias harus jujur." 39

Praktik dan resepsi politisi terhadap praktik ziarah di Bismo khususnya terhadap Alquran Bismo sangat menarik untuk diamati. Menurut penuturan juru kunci banyak politisi yang menziarahi kompleks petilasan Bismo untuk mendapatkan kemantapan dan keyakinan dalam mengambil keputusan. Sebagian mereka hendak mencalonkan diri sebagai kepala daerah, anggota legislatif dan yang paling banyak adalah para calon kepala desa di sekitar daerah Batang dan Pekalongan.

Motivasi para calon kepala desa yang menziarahi Bismo lebih banyak didorong untuk mendapatkan keyakinan sebelum melangkah. Sebagian karena masih ragu, sedangkan yang lainnya untuk menambah kemantapan. Bagi yang masih ragu dalam mengambil keputusan, ritual ziarah menyingkap hajat melalui Alquran Bismo ini

37 Ibid.

38 Afifur Rochman Sya'rani, “Assesing 'The Religious' and 'The Secular' in the Pilgrimage to Gus Dur's Grave," dalam Jurnal Sosiologi Agama, vol. 12, no. 2 (2018), 175.

${ }^{39}$ Wawancara dengan H. Turyono (Juru Kunci Makam Bismo) pada 22 Juli 2019. 
diyakini sebagai bentuk ikhtiar istikharah atau mencari petunjuk yang terbaik. Hal ini sebagaimana diungkapkan oleh Mbah Manten, yang saat mau maju sebagai kepala desa di Kabupaten Batang masih diliputi keraguan:

"Saya sebenarnya sudah menjabat kepala desa selama satu periode, ketika mau mencalonkan diri lagi saya ragu karena secara hitungan saya merasa akan mengalami kekalahan. Namun saya mencoba melakukan istikharah dengan menggunakan Alquran kuno yang ada di Bismo, apakah Allah akan memberikan petunjuk?"40

Namun bagi calon yang sudah mantab untuk maju pilihan kepala desa, kedatangan mereka menziarahi Bismo adalah untuk mendapatkan tambahan spirit dan kekuatan internal (internal power) dalam melakukan langkah. Hal ini seperti diungkapkan oleh Pak Bin yang mencalonkan diri sebagai kepada desa di daerah lain di Kabupaten Batang:

"Pada tahun 2011 saya mempunyai keinginan untuk ikut pencalonan kepala desa. Saya bertekad kesana untuk menemui juru kunci (H. Turyono) dengan menyampaikan maksud dan tujuan kedatangan saya dengan diikhtiari menggunakan Alquran Bismo." 41

Ritual yang dilakukan para calon kepala desa saat melakukan ritual ziarah menyingkap hajat ini tidak jauh berbeda antara satu dengan yang lainnya, yaitu mandi terlebih dahulu di "Tuk Limo" dengan membaca"niat ingsun gowak sial neng kene kerono Allah Ta áal" (saya niat membuang sial di sini karena Allah Ta'ala). Kemudian bersama juru kunci memasuki masjid dan menuju tempat penyimpanan Alquran kuno Bismo. Selama proses ritual pengalaman yang mereka alami berbeda-beda. Mbah Manten misalnya mengatakan:

"Saya dianjurkan untuk membuka Alquran Kuno Bismo sendiri, langsung dan spontan saya mendapatkan lembaran yang di dalamnya terdapat ayat yang kemudian diartikan oleh juru kunci dengan "Iika Allah menolong kamu maka tidak ada yang dapat mengalabkanmu, jika Allab membiarkan kamu (tidak memberi pertolongan) maka siapakah yang dapat menolong kamu (selain dari Allab)

\footnotetext{
40 Wawancara dengan Mbah Manten (Pelaku ritual menyingkap hajat) pada 23 Juli 2019.

${ }^{41}$ Wawancara dengan Pak Bin (Pelaku ritual menyingkap hajat) pada 27 Juli 2019.
} 
setelah itu? Namun saat menerawang saya tidak melihat gambar apapun." 42

Sementara itu Pak Bin mengungkapkan bahwa waktu melakukan ritual menyingkap hajat melalui Alquran Bismo, dia mendapatkan lembar yang terdapat ayat 62-66 surah al-Anfāl yang di antara isinya adalah "Jike ada dua puluh orang yang sabar di antaramu, niscaya mereka akan dapat mengalahkan dua ratus orang musuh. Dan jika ada seratus orang yang sabar di antaramu niscaya mereka akan dapat mengalabkan seribu dari pada orang kafir" (QS. al-Anfāl [8]: 65). Selain itu saat menerawang lembaran Alquran, dia melihat sosok macan berdiri dengan tahta dan tombak walaupun terlihat agak remang-remang. ${ }^{43}$

Pengalaman ritual ini memberi kesan tersendiri bagi pelakunya. Sakralitas ruang dan waktu yang dirasakan membentuk konstruksi keyakinan internal dalam diri mereka dan menyingkirkan ragam keraguan pilihan yang asalnya mengganggu hati. Setelah proses ritual, yang dirasakan mereka adalah keyakinan untuk melangkah dan mengambil keputusan. Hal ini nampak dari ungkapan Mbah Manten berikut ini:

"Pada saat saya membaca Alquran Kuno Bismo, saya terkesan pada awal surah Âli 'Imrān ayat 160 in yansur Alläh fa là ghäliba lakum "Jika Allah menolong kamu, maka tidak ada yang dapat mengalabkanmu." Kalimat tersebut telah menggugah jiwa dan memotivasi diri untuk yakin dan percaya dengan Allah kalau saya ikut kompetisi pencalonan kepala desa akan menang." ${ }^{44}$

Begitu juga yang dirasakan oleh Pak Bin. Dia mengatakan:

"Saya sangat senang masih bisa memegang Alquran peninggalan mbah Wali, saya meyakini kalau Alquran Kuno Bismo itu mempunyai nilai mistik. Nasihat yang disarankan oleh juru kunci memunculkan rasa optimis, percaya diri dan berani bersaing dengan lawan. Jadi saya kira Alquran tersebut ada efek magis." 45

Kemantapan yang timbul tersebut juga tidak terlepas dari peran juru kunci dalam memaknai ayat yang dibaca kemudian mengaitkan

42 Wawancara dengan Mbah Manten (Pelaku ritual menyingkap hajat) pada 23 Juli 2019.

43 Wawancara dengan Pak Bin (Pelaku ritual menyingkap hajat) pada 27 Juli 2019.

44 Wawancara dengan Mbah Manten (Pelaku ritual menyingkap hajat) pada 23 Juli 2019.

45 Wawancara dengan Pak Bin (Pelaku ritual menyingkap hajat) pada 27 Juli 2019. 
dengan tujuan yang hendak dicapai oleh para calon kepala desa tersebut. Pada kasus mbah Manten, meskipun ia tidak melihat gambar macan, namun dia sangat mantab sebab juru kunci mengatakan "nake Ayat iki sampean baca dengan yakin dan mantep insyaallah pasti terkabul" (kalau ayat ini kamu baca dengan yakin dan mantab insya Allah hajat kamu akan terkabul). ${ }^{46}$ Begitu juga saat juru kunci menafsirkan dan menjelaskan ayat 65 dari surah al-Anfāl yang diungkapkan kepada Pak Bin,

"Apa yang anda lakukan pastinya akan ada yang suka dan tidak suka, bila ada 100 orang yang tidak suka dengan pak Bin, pastinya akan ada orang yang suka dengan pak Bin 200 orang, begitu juga seterusnya. Walaupun memang membutuhkan perjuangan, insyallah hajat pak Bin akan dikabulkan". ${ }^{47}$

Terdapat dua amatan penting yang perlu mendapatkan perhatian terkait dengan ziarah politisi lokal ini. Pertama, ziarah para politisi tersebut tidak dapat dikategorikan sebagai ziarah dengan tujuan legitimasi politik (political legitimacy). ${ }^{48}$ Mereka melakukan ini bukan untuk membangun opini di kalangan konstituen bahwa mereka berafiliasi dan dekat dengan identitas tertentu. Mereka melakukan ziarah di Bismo cenderung sembunyi-sembunyi dan tidak diketahui konstituen. Sehingga ziarah mereka lebih bersifat privat untuk membangun kepercayaan diri (building convidence) dan meningkatkan kekuatan batin (increasing inner strength) melalui lapisan-lapisan keberkahan yang mereka yakini berada pada peninggalan dan petilasan para wali. Motivasi ziarah mereka berkelindan antara motivasi keagamaan dan motivasi sekuler-keduniaan. Di satu sisi praktik ziarah, tawasul dan tabaruk mereka merupakan ekspresi penghormatan kepada para wali. Namun disisi lain mereka menempatkan aktivitas itu sebagai instrument untuk meraih hajat keduniaan.

Kedua, sisi lain yang menarik adalah pandangan dan resepsi politisi lokal terhadap Alquran kuno Bismo. Sikap dan pandangan mereka lebih tepat dikategorikan sebagai interaksi modern umat Islam terhadap Alquran, bukan interaksi klasik sebagaimana pengkategorian Anna M. Gade dalam The Quran: An Introduction. ${ }^{49}$ Interaksi modern

\footnotetext{
46 Wawancara dengan Mbah Manten (Pelaku ritual menyingkap hajat) pada 23 Juli 2019.

${ }^{47}$ Wawancara dengan Pak Bin (Pelaku ritual menyingkap hajat) pada 27 Juli 2019.

48 Sya'rani, "Assesing 'The Religious'," 181-182.

49 Anna M. Gade, The Quran: An Introduction (Oxford: Oneworld, 2010), 161-162.
} 
adalah interaksi Muslim dalam konteks kehidupan tertentu yang menempatkan Alquran sebagai sumber keunikan yang berhubungan dengan praktik kehidupannya. Interaksi modern umat Islam terhadap Alquran setidaknya memunculkan tiga model resepsi, yaitu (1) resepsi estetis; (2); resepsi eksegetis (3) resepsi fungsional. ${ }^{50}$ Model pertama memposisikan Alquran sebagai keindahan seni baik pada sisi ornament, tulisan kaligrafinya ataupun pelantunannya. Model kedua memposisikan Alquran sebagai bahan bacaan yang dapat digali makna dan tafsirnya untuk kemudian dijadikan panduan dalam kehidupan. Sedangkan model resepsi ketiga memposisikan Alquran sebagai instrumen mistis dan ritus untuk tujuan tertentu.

Tradisi ziarah menyingkap hajat di kalangan politisi yang telah dipaparkan di atas memberikan gambaran bahwa resepsi para politisi terhadap Alquran kuno Bismo didominasi oleh resepsi fungsional, di mana Alquran dijadikan instrumen dalam satu ritual untuk menggapai hajat tertentu. Alquran kuno Bismo dianggap sebagai benda mistis dan magis yang memberikan petunjuk bagi langkah kehidupan para politisi dan dijadikan sumber inspirasi power untuk melakukan langkah politik. Resepsi eksegetis dalam ritual ziarah sebenarnya juga muncul, utamanya terkespresikan oleh juru kunci saat menafsirkan ayat yang tersingkap dan dibaca oleh politisi, dan kemudian dijadikan dasar untuk memberikan saran dan nasihat. Jika diperhatikan pembacaan yang dilakukan oleh juru kunci lebih dekat dengan model pembacaan ishärì atau bạtinì yang menekankan pada sisi esoteris Alquran dan bertumpu pada kekuatan batin pembaca. Memang substansi pembacaan juru kunci terhadap ayat-ayat Alquran tersebut jika diamati dalam skema struktur disiplin tafsir isyari mengandung beberapa kesenjangan, ${ }^{51}$ namun secara pragmatis pembacaan juru kunci tersebut mempunyai fungsi motivasi bagi para politisi.

\section{Kesimpulan}

Keberadaan petilasan dan benda-benda peninggalan para wali di desa Bismo menjadikan tempat tersebut memiliki nilai tersendiri dalam pandangan masyarakat. Terlebih para wali yang dikaitkan dengan desa Bismo adalah para wali penting dalam penyebaran Islam di Jawa, yaitu Sunan Bonang dan Sunan Kalijaga. Nilai historis, sakral

\footnotetext{
${ }^{50}$ Lihat Baidowi, "Resepsi Estetis," 20.

51 Jalāl al-Dīn 'Abd al-Raḥmān al-Suyūṭị, Al- Itqān fì Ulūm al-Qư'àn (Beirut: Dār alFikr al-'Ilmīyah, 1989), $17 \dot{5}$.
} 
dan keramat yang tersemat pada tempat ini, menjadikan Bismo menjadi salah satu destinasi penting bagi para peziarah utamanya di daerah Jawa.

Meksipun tempatnya di daerah pegunungan dan jangkauannya lumayan sulit, Bismo sudah lama dikenal sebagai tempat untuk tirakat ataupun ziarah. Para peziarah baik individu maupun rombongan dapat dikelompokkan menjadi dua, yaitu peziarah umum dan peziarah dengan hajat khusus. Keduanya sama-sama melakukan ritual ziarah layaknya para peziarah di tempat lain. Yang menjadikan berbeda adalah saat mereka mempunyai hajat khusus, sehingga mereka merasa perlu menghubungi juru kunci untuk melakukan ritual menyingkap hajat melalui Alquran kuno Bismo.

Dari sekian peninggalan para wali, Alquran kuno Bismo adalah peninggalan yang unik. Di samping masih dalam bentuk manuskrip tulisan tangan yang dipercayai sebagai tulisan sunan Bonang, mushaf kuno ini juga dijadikan media para peziarah untuk istikharah, meyakinkah langkah mereka ke depan. Ritual ini baru muncul pada tahun delapan puluhan. Di antara para peziarah yang sering melakukan ritual ini adalah para politisi lokal yang akan ikut kontestasi pilihan kepala desa di sekitar Batang dan Pekalongan.

Kitab suci Alquran Bismo diyakini mempunyai nilai fungsional yang sakral sehingga praktik ritual ziarah 'menyingkap hajat' melalui Alquran kuno Bismo masih berjalan hingga sekarang. Konstruksi pemikiran seperti ini memberi nuansa ritual ziarah yang dilakukan para politisi bukan sekedar didorong oleh motifasi spiritualitas keagamaan, namun juga berkelindan dengan motivasi sekuler keduniaan. Para politisi lokal memandang Alquran Kuno Bismo tidak hanya mempunyai fungsi ornamen dan sebagai bahan bacaan, namun mereka memposisikannya layaknya benda mistis dan magis. Melalui ritual ini mereka berharap mendapatkan pencerahan batin dan keyakinan atas pilihan langkah yang akan mereka lakukan. Para pelaku ritual ini meyakini bahwa apa yang mereka lakukan adalah bentuk implementasi kreatif yang tidak keluar dari koridor prinsip ajaran para wali yang sudah mentradisi di wilayah Jawa.

Dengan menggunakan kerangka living Quran-Hadis dan metode etnografi, tulisan ini mengungkap bagaimana sejarah dan praktik ritual ziarah menyingkap hajat di pemakaman Bismo, serta bagaimana resepsi politisi lokal terhadap ritual ziarah tersebut. Watak aktivitas ziarah memang selalu melibatkan dua kutub yaitu duniawi-ukhrawi 
dan juga material-spiritual. Oleh sebab itu kajian mengenai ziarah harus bersifat multidisiplin. Tulisan ini memaparkan aspek historis, keagamaan dan sosial politik dari praktik ziarah di pemakaman Bismo, namun belum mengungkap aspek lain yang juga penting di lapangan, terutama aspek bahasa dan juga ekonomi.

\section{DAFTAR PUSTAKA}

Baghdādī (al), Abū Bakr Aḥmad b. 'Alī. Tārikeh al-Baghdād. Beirut: Dār al-Kutub al-'Ilmīyah, 1931.

Baidowi, Ahmad. "Resepsi Estetis Terhadap Alquran," dalam Dinamika Studi al-Quran. Yogyakarta: Idea Press, 2009.

Bukhārī (al), Abū 'Abd Allāh Muḥammad b. Ismā’îl. Al-Jāmi' al-Ṣaḥịh.

Kairo: al-Mațba'ah al-Salafiyah, $1403 \mathrm{H}$.

Chaer, Moh. Toriqul. "Aspek Religiousitas Masyarakat Peziarah Makam Syaykh Abdul Muhyi Pamijahan Tasikmalaya." Maraji”: Jurnal Studi Keislaman, Vol. 1, No. 2, (2015).

Chambert-Loir, Henri dan Claude Guillot (eds). Ziarah dan Wali di Dunia Islam. Diterjemahkan oleh Jean Couteau, Ari Anggari Harapan, Machasin, Andrée Feillard. Jakarta: Serambi, 2007.

Duwaydah, Nafīsah. "Al-Mu'taqadāt wa al-Ṭuqūs al-Khāṣṣah bi alUḍriḥah fì al-Jazāìr Khilāl al-Fatrah al-'Uthmānīyah.” Jurnal Insāniyāt, vol. 68, (2015).

Gade, Anna M. The Quran: An Introduction. Oxford: Oneworld, 2010. Ḥasanī (al), Hishām b. Muḥammad Hayjar. Al-Tabarruk bi al-Saalihịnn. Maroko: Dār al-Rashād al-Hadīthah, t.th.

Jailānī, Sirāj. "Ziyārah al-Uḍihịah wa Athāruhā fì al-Mu'taqadāt alSha'bìyah: Ḍarịh Sayyidī Yūsuf al-Sharîf Namūdhajan.” Tesis, Universitas Aboe Bekr Belkaid, Fakultas Ilmu Humaniora dan Sosial, 2014/2015.

Jamhari. "In The Center of Meaning: Ziarah Tradition ini Java." Studia Islamika. vol. 7, no. 1 (2000).

Jāwī (al), Muḥammad Nawāwī b. 'Umar. Nașā’ị̣ al-Tbād Sharḥ alMunabbihät 'alà al-Isti'dād li Yawm al-Ma'àd. Beirut: Dār al-Kutub al-'Ilmīyah, 2015. 
Mālikī (al), Muḥammad b. 'Alawī. Al-Ziyārah al-Nabawīyah. Makkah: Maktabah al-Awqāf wa al-Shu'ūn, t.th. . Mafābìm Yajib an Tusahah. Beirut: Dār al-Kutub al-'Ilmīyah, 2016.

Muhammad, Yūsuf Khațāār. Al-Mawsū'ah al-Yüsufiyan fì Bayān Adillat al-Süfíyah. Damaskus: Dār al-Taqwā, t.th.

Mujib, M Misbahul. "Fenomena Tradisi Ziarah Lokal Dalam Masyarakat Jawa: Kontestasi Kesalehan, Identitas Keagamaan Dan Komersial." IBD A': Jurnal Kajian Islam Dan Budaya, vol. 14, no. 2 (2016).

Najitama, Fikria. "Ziarah Suci dan Ziarah Resmi: Makna Ziarah pada Makam Santri dan Makam Priyayi." IBDA': Jurnal Kajian Islam dan Budaya, vol. 11, no. 1 (2013).

Șadīq (al), Thiyāqah “Al-Muqaddas wa al-Qabīlah: al-Mumārasah alIḥtifālīyah ladā al-Mujtama‘āt al-Quṣūrīyah bi al-Janūb alGharbī al-Jazā'irī." Disertasi, Universitas Wahran Aljazair, Fakultas Ilmu Sosial, 2014.

Suyūṭī (al), Jalāl al-Dīn 'Abd al-Raḥmān. Al-Itqān fì Ulūm al-Qư'ān. Beirut: Dār al-Fikr al-'Ilmīyah, 1989.

Sya'rani, Afifur Rochman. “Assesing 'The Religious' and 'The Secular' in the Pilgrimage to Gus Dur's Grave." Jurnal Sosiologi Agama, vol. 12, no. 2 (2018).

Syam, Nur. Islam Pesisir. Yogyakarta: LKIS, 2005.

- Madzhab-madzhab Antropologi. Yogyakarta: LKIS Group, 2012.

Thohir, Mudjahirin. Orang Islam Jawa Pesisiran. Semarang: Fasindo Press, 2006.

Woodward, Mark R. Islam Jawa, Kesalehan Normatif Versus Kebatinan. Diterjemahkan oleh Hairus Salim HS. Yogyakarta: LKIS, 2008. Yahya, Mohammad. "Fungsi Simaan Alquran Bagi Santri Pondok Pesantren Sunan Pandanaran, Sleman, Yogyakarta." Religia: Jurnal Ilmu-Ilmu Keislaman, vol. 20, no. 2 (2017). 
Arif Chasanul Muna \& Ahmad Fauzan

\section{WAWANCARA}

Wawancara dengan Pak Bin (Pelaku ritual menyingkap hajat) pada 27 Juli 2019.

Wawancara dengan H. Turyono (Juru Kunci Makam Bismo) pada 16 Juli 2019.

Wawancara dengan H. Turyono (Juru Kunci Makam Bismo) pada 22 Juli 2019.

Wawancara dengan Mbah Manten (Pelaku ritual menyingkap hajat) pada 23 Juli 2019.

Wawancara dengan Suwanto (Warga Bismo) pada 20 Juli 2019. 